\title{
Erratum
}

\section{miR-21 ablation and obeticholic acid ameliorate nonalcoholic steatohepatitis in mice}

\author{
Pedro M Rodrigues, Marta B Afonso, André L Simão, Catarina C Carvalho, Alexandre Trindade, António Duarte, Pedro M Borralho, \\ Mariana V Machado, Helena Cortez-Pinto, Cecília MP Rodrigues and Rui E Castro
}

Cell Death and Disease (2017) 8, e2825; doi:10.1038/cddis.2017.246; published online 25 May 2017

Correction to: Cell Death and Disease (2017) 8, e2748; doi:10.1038/cddis.2017.172; published online 13 April 2017

Since the publication of this paper, it has been noted that Figure 1 was split to appear in two different pages resulting in panels $(\mathrm{a})-(\mathrm{g})$ being displaced, rendering the figure incomprehensible.

The figure has been reformatted to appear on one page.

The corrected article appears online together with this erratum. The publishers apologize for any inconvenience this may have caused. (c) (i) Cell Death and Disease is an open-access journal published by Nature Publishing Group. This work is licensed under a Creative Commons Attribution 4.0 International License. The images or other third party material in this article are included in the article's Creative Commons license, unless indicated otherwise in the credit line; if the material is not included under the Creative Commons license, users will need to obtain permission from the license holder to reproduce the material. To view a copy of this license, visit http://creativecommons.org/licenses/by/4.0/

(C) The Author(s) 2017 